\title{
System of control in the organization of pulmonary rehabilitation of persons with chronic obstructive pulmonary disease
}

\author{
Tymruk-Skoropad K.A., Pavlova Iu.O., Mazepa M.A. \\ Lviv State University of Physical Culture
}

\section{DOI: https://doi.org/10.34142/HSR.2019.05.03.08}

\section{Abstract}

The aim: to substantiate the structural components of the control system aimed at improving the physical therapist's work during pulmonary rehabilitation (PR) of COPD persons.

Materials and methods. Analysis and generalization of the data of the special scientific and methodological literature on the issues of physical therapy of patients with chronic obstructive pulmonary disease; method of analysis of medical records; elaboration of Internet sources, including databases of evidence based medical literature.

Results. The control system, which is reasonable to be implemented at three stages (preliminary, current, final) of the process of physical therapy (PT) and PR of patients with COPD, is substantiated.

The control system within the competence of the physical therapist provides for rehabilitation examination (preliminary control), monitoring (current control) and final evaluation of certain indicators. There were 5 groups of main indicators: quality of life/ activity and participation, disease course, body functions, body structures, educational competence. For the selected groups of indicators, the selection of measuring instruments was made, the features of their application at different stages were outlined, the values of the minimum clinically significant difference for the selected indicators were given.

Conclusions. The process of pulmonary rehabilitation of people with COPD needs to be evaluated and monitored for its effectiveness in accordance with the expected results.

The monitoring system allows to track all changes in the patient's health and functioning, regulate the intervention and its intensity, evaluate both the individual physical therapy session and the effectiveness of the entire program.

One of the criteria of the control system is the effectiveness of PT and PR, which is evaluated on the basis of the dynamics and direction of changes of the studied indicators, their compliance with the expected result and taking into account the values of the minimal clinically significant difference for the evaluated indicators.

Key words: physical therapy, COPD, efficacy, International Classification of Functioning, ICF.

\section{Анотація}

Тимрук-Скоропад К.А., Павлова Ю.О., Мазепа М.А. Система контролю в організації легеневої реабілітації осіб з хронічним обструктивним захворюванням легень

Мета дослідження - обгрунтувати структурні компоненти системи контролю, спрямованої на підвищення ефективності роботи фізичного терапевта під час легеневої реабілітації осіб з ХОЗЛ.

Матеріали і методи

Аналіз й узагальнення даних спеціальної науково-методичної літератури з питань фізичної терапії при хронічному обструктивному захворюванні легень; метод аналізу медичної документації; опрацювання інтернет-джерел, зокрема баз науково-доказової медичної літератури.

Результати. Обґрунтовано систему контролю, яку доцільно реалізовувати на трьох етапах (попередньому, поточному, підсумковому) процесу фізичної терапії та легеневої реабілітації пацієнтів із ХОЗЛ.

Система контролю в межах компетенції фізичного терапевта передбачає проведення реабілітаційного обстеження (попередній контроль), моніторингу (поточний контроль) та завершального оцінювання визначених показників. Виокремлено 5 груп основних індикаторів: якість життя/ активність та участь, перебіг захворювання, функції організму, структури організму, освітня компетентність. Для обраних груп індикаторів зроблено підбір вимірників, окреслено особливості їх застосування на різних етапах, подано величини мінімальної клінічно значимої різниці для обраних показників.

Висновки. Процес легеневої реабілітації осіб із ХОЗЛ потребує оцінювання та контролю її ефективності відповідно до очікуваних результатів.

Система контролю дає змогу відслідковувати усі зміни в стані здоров'я та функціонуванні пацієнта, регулювати втручання та його інтенсивність, оцінювати як окремий сеанс фізичної терапії, так і результативність усієї програми.

Одним із критеріїв системи контролює результативність ФТ та ЛР, яка оцінюється на основі динаміки та напрямку змін досліджуваних показників, їх відповідності очікуваному результату та врахуванні величин мінімальної клінічно значимої різниці для оцінюваних показників

Ключові слова: фізична терапія, ХОЗЛ, ефективність, Міжнародна класифікація функціонування, МКФ.

Анотация

Система контроля в организации легочной реабилитации лиц с хронической обструктивной болезнью легких.

Цель исследования. Обосновать структурные компоненты системы контроля, направленной на повышение эффективности работы физического терапевта во время легочной реабилитации лиц с ХОБЛ.

Материалы и методы исследования. Анализ и обобщение данных специальной научно-методической литературы по вопросам физической терапии при хроническом обструктивном заболевании легких; метод анализа медицинской документации; обработки интернет-источников, в том числе баз научно-доказательной медицинской литературы.

Результат. Обоснованно систему контроля, которую целесообразно реализовывать на трех этапах (предыдущем, текущем, итоговом) процеса физической терапии и легечной реабилитации пациентов с ХОБЛ.

Система контроля в пределах компетенции физического терапевта предусматривает проведение реабилитационного обследования (предварительный контроль), мониторинга (текүщий контроль) и завершающего оценивания показателей. Выделены 5 групп основных индикаторов: качество жизни / активность и участие, течение заболевания, функции организма, структуры организма, образовательная компетентность. Для избранных групп индикаторов сделано подбор измерителей, определены особенности их применения на различных этапах, представлены величины минимальной клинически значимой разницы для избранных показателей.

Выводы. Процесс легочной реабилитации лиц с ХОБЛ требует оценки и контроля ее эффективности в соответствии с ожидаемым результатам.

Система контроля позволяет отслеживать все изменения в состоянии здоровья и функционировании пациента, регулировать вмешательства и их интенсивность, оценивать как отдельный сеанс физической терапии, так и результативность всей программы.

Одним из критериев системы контроля является результативность ФТ и ЛР, которая оценивается на основе динамики и направления изменений исследуемых показателей, их соответствия ожидаемому результату и учете величин минимальной клинически значимой разницы для оцениваемых показателей.

Ключевые слова: физическая терапия, ХОБЛ, эффективность, Международная классификация функционирования, МКФ. 


\section{Introduction}

Pulmonary rehabilitation (PR) is a complex intervention that helps to improve physical and mental state, as well as a level of functioning of people with chronic respiratory diseases, and contributes to the formation and development of health-conscious behavior skills [1]. Such rehabilitation requires a thorough and comprehensive assessment of the patient's condition that in turn, will provide the necessary information for the use of mandatory and/or variable components of therapy to achieve the most positive effect [2]. Professionals of various specialties are involved in the implementation of PR programs, in particular, physical therapists are involved in the assessment of physical fitness and functional state of patients with chronic obstructive pulmonary disease (COPD) [3], definition of the rehabilitation diagnoses and tasks, implementation of the planned physical therapy programs, conducting lectures and practical training under the implementation of the PR educational component, etc.

Following international standards, the development and reform of rehabilitation assistance is one of the priorities of the Ministry of Health of Ukraine [4, 5]. The position of physical therapist has been introduced in healthcare institutions [6] by order of the Ministry of Health of Ukraine, and the introduction of the International Classification of Functioning, Disability and Health (ICF) has been launched in the region [7]. It has been assumed that the ICF will become the basis for planning rehabilitation measures, as well as developing and implementation social policies. In the rehabilitation system, it is the ICF that will be used as a comprehensive clinical tool for promoting mutual understanding between all members of the multidisciplinary team, which is coherent and in turn effective exchange of information about the patient's condition, and assessment of the quality of rehabilitation [8].

Because of the level and quality of providing rehabilitation assistance to people with COPD, and considering the development tendency of the rehabilitation system in Ukraine, it is not enough to outline only the content and components of the PR and the role of physical therapists in it. Transparent algorithms for the interaction of physical therapists with other specialists from the team who have used the ICF tools, as well as the substantiation and implementation of a modern control system for monitoring the effectiveness of physical therapy (PT) in the PR program, are needed.
The aim of the study has been to substantiate the structural components of a control system aimed at improving the performance of physical therapist's work during pulmonary rehabilitation of people with COPD.

\section{Materials and methods}

Analysis and consolidation of data of special scientific and methodical literature on the issues of PT in COPD; methods for analyzing medical records; processing online sources, in particular, databases of scientific evidence-based medical literature.

\section{Results}

The main goal of PR for persons with COPD is to reduce the symptoms of the disease, decrease the level of the patient's disability, increase their physical and social activity and improve the quality of life [9]. Physical therapy is an integral part of the rehabilitation system for people with COPD, and physical therapists are necessary members of multidisciplinary teams. Their role is to conduct rehabilitation examination within their competencies, formulate goals, objectives, and prognosis for patients receiving PT, create individual therapy programs with their implementation, ensure ongoing monitoring of the effectiveness of PT and the patient's condition, and finally evaluate working results.

The process of PR and PT for people with COPD is an activity aimed at achieving the goal in accordance with the planned/defined tasks, and therefore requires monitoring and evaluation of effectiveness. The content of monitoring is to accumulate information with its subsequent systematization and processing, identify factors causing inconsistency between the planned/defined tasks, and the obtained result. Because of the need to substantiate approaches to the formation of an assessment and control system in the process of PT and PR of people with COPD, - specialists who provide rehabilitation assistance are the subjects of control at this management level.

The control system provides for the selection and development of specific standards, indicators, indices, evaluation, permissible variations, and also contains corrective actions to achieve the most optimal result. An indicator is a unit of the system by means of which it is possible to track changes that have occurred as a result of the intervention of a physical therapist, results achieved by his/her actions or program results in general.

When choosing indicators, it is advisable to apply a number of criteria, in particular, verification 
of conformity (whether that indicator allows you to measure positive changes during the implementation of distinct phases); sensitivity (ability to respond to possible changes); availability (easiness in obtaining data); credibility (data are valid for the required period of time); simplicity (no difficulties in calculating data); universality (the data are obvious and clear to all team members); frugality (the cost of obtaining data corresponds to the expected benefits) $[10,11]$.

Qualitative (displayed as the judgment of the patient or physical therapist) and quantitative (can be determined in quantitative equivalent) data are of great importance to physical therapists. According to the results of the analysis of scientific and methodological literature and taking into account the ICF system and the basic set of the ICF categories for obstructive pulmonary diseases, we can distinguish the main groups of indicators that are most often used by physical therapists (indicators have been listed in order from the most to the least frequently used ones) to evaluate the effectiveness during the PR:

1) quality of life/ activity and involmenent;

2) the course of the disease (symptoms, their intensity and manifestation, exacerbation, seeking health care, and hospitalization);

3) body functions (specific mental functions, cardiovascular system functions, additional functions and sensations associated with the cardiovascular and respiratory systems, respiratory system functions, joint and bone functions, muscle functions, and movement functions);

4) body structure;

5) educational competence (information awareness, literacy and education of patients with COPD).

Evaluation of these indicators allows making the physical therapy program as focused on the individual patient as possible, tracking changes in his/her condition during/after particular intervention, and upon completion of the therapy program.

An index is a measuring tool that in turn, can also be qualitative and quantitative; an indicator can be comprehensively assessed using a single one or a group of indices (Table 1), in particular, some indices can provide a comprehensive (integrated) assessment of several indicators. Fundamentally, indices that track changes during pulmonary rehabilitation and the physical therapist's working performance are sociological (questionnaires and scales), instrumental research methods (spirometry, pulse oximetry, tonometry, etc.), or clinical tests (6-minute walk test, ISWT).

In general, the control system itself consists of three stages: (1) preliminary (rehabilitation examination), (2) current and (3) final (Table 2). At each stage, the control task, and accordingly the indicators and their indices are different.

Indicators and their evaluation tools

Table 1

\begin{tabular}{|c|c|c|c|}
\hline Indicator groups & Indicators & Indices & Parameter \\
\hline \multirow[t]{2}{*}{$\begin{array}{l}\text { Quality of life / } \\
\text { activity and } \\
\text { involvement }\end{array}$} & Quality of life & $\begin{array}{l}\text { Recommended: } \\
\text { SGRQ } \\
\text { CRQ } \\
\text { Alternative: } \\
\text { SF-36 } \\
\text { EQ-5D }\end{array}$ & standard of living \\
\hline & $\begin{array}{l}\text { Activity and } \\
\text { involvement }\end{array}$ & $\begin{array}{l}\text { Supplementary: } \\
\text { PSPP } \\
\text { LHS }\end{array}$ & $\begin{array}{l}\text { self-identification of a physical fitness } \\
\text { restrictions on the level of functioning }\end{array}$ \\
\hline \multirow[t]{2}{*}{$\begin{array}{l}\text { Course of the } \\
\text { disease }\end{array}$} & $\begin{array}{l}\text { Symptoms, their } \\
\text { intensity and } \\
\text { manifestation }\end{array}$ & $\begin{array}{l}\text { Recommended: } \\
\text { mMRC } \\
\text { CAT } \\
\text { CCQ } \\
\text { BODE index } \\
\text { Alternative: } \\
\text { Borg Scale } \\
\text { BDI/TDI } \\
\end{array}$ & $\begin{array}{l}\text { dyspnea level } \\
\text { manifestation of symptoms of the disease } \\
\text { manifestation of symptoms of the disease } \\
\text { integrated index* } \\
\text { dyspnea level } \\
\text { dyspnea level }\end{array}$ \\
\hline & Exacerbation & $\begin{array}{l}\text { Recommended: } \\
\text { period to exacerbation after PR } \\
\text { annual total }\end{array}$ & $\begin{array}{l}\text { period of time (weeks, months) to exacerbation } \\
\text { after PR } \\
\text { frequency of exacerbations per annum }\end{array}$ \\
\hline
\end{tabular}




\begin{tabular}{|c|c|c|c|}
\hline & $\begin{array}{l}\text { Health care visit to a } \\
\text { doctor }\end{array}$ & $\begin{array}{l}\text { Recommended: } \\
\text { number of requests made for } \\
\text { doctor's assistance } \\
\text { Supplementary: } \\
\text { Number of health care provided }\end{array}$ & $\begin{array}{l}\text { frequency of health care visits } \\
\text { scale of provided health care services }\end{array}$ \\
\hline & Hospitalization & $\begin{array}{l}\text { Supplementary: } \\
\text { number of hospitalizations } \\
\text { number of patient bed-days }\end{array}$ & $\begin{array}{l}\text { annual hospitalization rate } \\
\text { periods of hospitalization }\end{array}$ \\
\hline \multirow{8}{*}{ Body functions } & Respiratory function & $\begin{array}{l}\text { Recommended: } \\
\text { spirometry } \\
\text { respiratory rate measuring } \\
\text { oximetry } \\
\text { Supplementary: } \\
\text { Stange test } \\
\text { Genchi test } \\
\text { pressure in the oral cavity during } \\
\text { breathing }\end{array}$ & $\begin{array}{l}\text { respiratory function indicators } \\
\text { respiratory rate } \\
\mathrm{O}_{2} \text { saturation } \\
\text { inspiratory breath-holding time } \\
\text { expiration breath-holding time } \\
\text { respiratory muscle strength }\end{array}$ \\
\hline & $\begin{array}{l}\text { Cardiovascular } \\
\text { function }\end{array}$ & $\begin{array}{l}\text { Recommended: } \\
\text { pulsometry } \\
\text { tonometry }\end{array}$ & $\begin{array}{l}\text { heart rate } \\
\text { arterial pressure }\end{array}$ \\
\hline & $\begin{array}{l}\text { Complementary } \\
\text { functions and } \\
\text { feelings associated } \\
\text { with the } \\
\text { cardiovascular and } \\
\text { respiratory systems }\end{array}$ & $\begin{array}{l}\text { Recommended: } \\
\text { 6MWT } \\
\text { ISWT } \\
\text { ESWT }\end{array}$ & $\begin{array}{l}6 \mathrm{MWD} \\
\text { the distance travelled } \\
\text { the distance travelled ot the time spent for } \\
\text { covering the distance }\end{array}$ \\
\hline & Muscle function & $\begin{array}{l}\text { Recommended: } \\
\text { 6MWT } \\
\text { ISWT } \\
\text { ESWT }\end{array}$ & $\begin{array}{l}6 M W D \\
\text { the distance travelled } \\
\text { the distance travelled at the time spent for } \\
\text { covering the distance }\end{array}$ \\
\hline & & $\begin{array}{l}\text { Supplementary: } \\
\text { dynamometry } \\
\text { cycle ergometry }\end{array}$ & $\begin{array}{l}\text { muscle strength of lower extremities } \\
\text { muscle strength of lower extremities }\end{array}$ \\
\hline & Movement function & $\begin{array}{l}\text { Alternative: } \\
\text { STS test }\end{array}$ & balance and coordination, leg muscle strength \\
\hline & $\begin{array}{l}\text { Specific mental } \\
\text { functions }\end{array}$ & $\begin{array}{l}\text { Recommended: } \\
\text { HADS }\end{array}$ & anxiety and depression level \\
\hline & $\begin{array}{l}\text { Joint and bone } \\
\text { functions }\end{array}$ & $\begin{array}{l}\text { Supplementary: } \\
\text { chest circumference measurements }\end{array}$ & $\begin{array}{l}\text { thoracic excursion } \\
\text { inspiratory thoracic excursion } \\
\text { expiratory thoracic excursion }\end{array}$ \\
\hline \multirow{3}{*}{ Body structure } & $\begin{array}{l}\text { Head and neck area } \\
\text { structure }\end{array}$ & \multirow{3}{*}{$\begin{array}{l}\text { Recommended: } \\
\text { examination }\end{array}$} & \multirow{3}{*}{$\begin{array}{l}\text { posture, } \\
\text { shape, } \\
\text { deformation }\end{array}$} \\
\hline & $\begin{array}{l}\text { Shoulder girdle } \\
\text { structure }\end{array}$ & & \\
\hline & Structure of the torso & & \\
\hline $\begin{array}{l}\text { Educational } \\
\text { competence }\end{array}$ & $\begin{array}{l}\text { COPD patient's } \\
\text { awareness, literacy } \\
\text { and education }\end{array}$ & $\begin{array}{l}\text { Recommended: } \\
\text { Bristol COPD Knowledge } \\
\text { Questionnaire } \\
\text { Alternative: } \\
\text { COPD-Q } \\
\text { UCOPD }\end{array}$ & COPD level of knowledge \\
\hline
\end{tabular}

Notes:

SGRQ - St. George's Respiratory Questionnaire for assessing respiratory function;

CRQ - Chronic Respiratory Disease Questionnaire

SF-36 - The Short Form-36;

EQ-5D - The EuroQol five-dimensional questionnaire;

PSPP - Physical Self-Perception Profile;

LHS - London Handicap Scale;

mMRC - Modified British Medical Research Council Questionnaire

CAT - COPD Assessment Test

CCQ - COPD Control Questionnaire;

BODE index - integrated indicator involving FEV1, 6MWD, mMRC, body mass index;

$\mathrm{BDI} / \mathrm{TDI}$ - Baseline Dyspnea Index / Transition Dyspnea Index;

$\mathrm{RR}$ - raspiration rate;

HR - heart rate;

AP - arterial pressure;

6MWT - the 6-Minute Walk Test

6MWD - 6-minute walking distance covered by a patient while performing the 6MWT

ISWT - Incremental shuttle walking test;

ESWT - Endurance shuttle walk test;

STS test - sit and stand test;

HADS - the Hospital Anxiety and Depression Scale;

TE - thoracic excursion;

COPD-Q - Chronic Obstructive Pulmonary Disease knowledge Questionnaire;

UCOPD - Understanding COPD questionnaire; * - integrated assessment of several groups of indicators. 
Characteristics of the monitoring system of physical therapy in pulmonary rehabilitation of persons with COPD
Unit/Component
Description
Contents

\begin{tabular}{|c|c|c|}
\hline \multirow{3}{*}{ Control stages } & Preliminary & $\begin{array}{l}\text { rehabilitation examination using the most complete list of } \\
\text { examination methods and indicators }\end{array}$ \\
\hline & Current & $\begin{array}{l}\text { - prior to each PT session; } \\
\text { - in the course of the PT session; } \\
\text { - after the PT session; } \\
\text { - at specified intervals following the prolonged PT (stage } \\
\text { examination) }\end{array}$ \\
\hline & Final & is carried out upon the completion of the PT and PR programs \\
\hline $\begin{array}{l}\text { Goal of } \\
\text { monitoring }\end{array}$ & $\begin{array}{l}\text { to ensure the achievement } \\
\text { rehabilitation assistance to pat }\end{array}$ & $\begin{array}{l}\text { of the strategic goal - providing high-quality and effective } \\
\text { ients with COPD }\end{array}$ \\
\hline $\begin{array}{l}\text { Monitoring } \\
\text { subject }\end{array}$ & $\begin{array}{l}\text { Specialist who provides } \\
\text { rehabilitation assistance }\end{array}$ & physical therapist, physical rehabilitation specialist \\
\hline \multirow[b]{2}{*}{$\begin{array}{l}\text { Monitoring } \\
\text { object }\end{array}$} & Patient - a person with COPD & $\begin{array}{l}\text { compliance of the results of PT and PR with the overall aims, } \\
\text { goals, and patient's expectations formulated at the beginning of } \\
\text { the rehabilitation }\end{array}$ \\
\hline & $\begin{array}{l}\text { Quality of life/activity and } \\
\text { involment; the course of the } \\
\text { disease; body functions; body } \\
\text { structure; educational } \\
\text { competency }\end{array}$ & $\begin{array}{l}\text { - dynamics and direction of changes in the studied parameters } \\
\text { during and after the PT and PR; } \\
\text { - compliance of changes in the studied indicators with the } \\
\text { expected results, goals and objectives formulated at the } \\
\text { beginning of the PT and PR }\end{array}$ \\
\hline \multirow{3}{*}{ Monitoring tools } & $\begin{array}{l}\text { Questionnaires / checklists / } \\
\text { scales }\end{array}$ & $\begin{array}{l}\text { quality of life / activity and involment; the course of the disease; } \\
\text { educational competency }\end{array}$ \\
\hline & $\begin{array}{l}\text { Instrumental methods of } \\
\text { investigation }\end{array}$ & body functions, body structures \\
\hline & Clinical tests & body structures \\
\hline \multirow[t]{2}{*}{$\begin{array}{l}\text { Standards and } \\
\text { Criteria }\end{array}$} & Patient-oriented & $\begin{array}{l}\text { - patient rights have been respected in accordance with current } \\
\text { legislation; } \\
\text { - ethical and deontological standards in the field of healthcare } \\
\text { have been met; } \\
\text { - patient's expectations, needs and values have been taken into } \\
\text { consideration }\end{array}$ \\
\hline & Efficiency & $\begin{array}{l}\text { - changes in the clinical condition (taking into account the value } \\
\text { of the MCID for the chosen research method); } \\
\text { - positive dynamics of indicators [12], achievement of expected } \\
\text { results }\end{array}$ \\
\hline \multirow{3}{*}{$\begin{array}{l}\text { Typical } \\
\text { correction } \\
\text { actions }\end{array}$} & $\begin{array}{l}\text { Not to interfere in the PT and } \\
\text { PR processes }\end{array}$ & when actual results meet established standards and criteria \\
\hline & Make adjustments & $\begin{array}{l}\text { if scheduled interventions cannot be performed; when } \\
\text { rehabilitation interventions do not have the expected effect and } \\
\text { are not efficient }\end{array}$ \\
\hline & $\begin{array}{l}\text { Revise standards, criteria, } \\
\text { goals and objectives }\end{array}$ & $\begin{array}{l}\text { in case of overestimated expected results, unrealistic } \\
\text { achievement of goals; unexpected changes in the patient's } \\
\text { condition and rehabilitation conditions }\end{array}$ \\
\hline
\end{tabular}

Notes: MCID - minimal clinically important difference; PT - physical therapy; PR - pulmonary rehabilitation.

The most comprehensive list of indices has been used at the stage of preliminary and final control carried out before the beginning (initial or rehabilitation examination) and upon completion (final examination or evaluation) of PT, respectively. The preliminary stage of control makes it possible to: 
1) fully assess the functional state of body systems and those structures and functions that primarily cause a decrease in exercise tolerance, shortness of breath, and impaired functioning;

2) determine the rehabilitation diagnosis and prognosis for a particular patient;

3) take into account the functional state of the cardiorespiratory and musculoskeletal systems, the level of physical performance, functionality, quality of life, manifestations of symptoms of the disease in order to select a strategy and individualize the physical therapy program;

4) accumulate all data necessary to track progress, evaluate the effectiveness and efficiency of PT in the future.

The objectives of the final monitoring phase are as follows:

1) to evaluate the result of physiotherapeutic intervention;

2) to identify changes in the functional state of the cardiovascular and respiratory systems, the level of physical performance, functioning and quality of life after the physical therapy program;

3) based on the results obtained, give recommendations for PT at home, regarding the necessary measures for the person examined and strategically plan the further pulmonary rehabilitation.

Current control includes sub-stages when the entire or only a partial set of indices is used (Table. 1 ); it would be useful to carry out the ongoing monitoring:

- before each PT session;

- $\quad$ in the course of the PT session;

- after a PT session;

- at specified intervals following the prolonged PT (stage examination).

The goals of monitoring patients with COPD

before, during, and after each PT session are to:

1) assess the current condition of the patient before the PT session;

2) consider the existing patient's condition for the correction of the PT program in the course of the current session;

3) monitor the patient's condition over the session;

4) assess the time-critical effectiveness and feasibility of PT measures;
5) evaluate the effectiveness of the entire PT session.

The ongoing monitoring requires the study of such indicators and the use of such indices that allow monitoring the slightest changes in the patient's condition and general state in order to change physiotherapeutic interventions accordingly. First of all, these are the indicators of the respiratory and cardiovascular systems (rate of respiration, heart rate, blood pressure, $\mathrm{SpO}_{2}$, and spirometry).

The purpose of the stage examination is to assess the effect of PT on the main indicators of the body systems, manifestations of the disease, quality of life and physical performance in order to identify the preconditions for adjusting the PT programs, and motivating the patient to further activities.

Provided that the PT program has been designed for a more extended period, it is advisable to determine indicators during the stage examinations that do not change quickly. However, with time, they may testify to the effectiveness of the intervention and indicate the direction of changes in the patient's condition (Table 3 ).

One of the criteria of the control system is the effectiveness of the PT and PR, which should be evaluated based on the dynamics and direction of changes in the studied indicators and their compliance with the expected result. It is advisable to take into account the value of the minimum clinically important difference (MCID) in order to track these changes and consider their clinical significance (Table 3).

\section{Discussion}

Pulmonary rehabilitation programs are multicomponent and multidisciplinary that require clear organization to ensure their implementation, understandable interaction between subjects and with rehabilitation objects, effective and not excessive procedures for assessing and monitoring the patient's condition before, during, and after rehabilitation, and correction mechanisms for rehabilitation interventions. However, along with a large number of clinical guidelines, systematic reviews and randomized clinical trials devoted to the description of pulmonary rehabilitation components and their contents, analysis of their effectiveness, - the control system in organizing pulmonary rehabilitation, in general, and in PT in particular, has not been described. 
Table 3

The use of indices at different monitoring stages

\begin{tabular}{|c|c|c|c|c|c|c|c|c|}
\hline \multirow{3}{*}{$\begin{array}{l}\text { Groups of } \\
\text { indicators }\end{array}$} & \multirow{3}{*}{ Indices } & \multirow{3}{*}{ MCID } & \multicolumn{6}{|c|}{ Stage } \\
\hline & & & \multirow{2}{*}{$\begin{array}{c}\text { prelimina } \\
\text { ry }\end{array}$} & \multicolumn{4}{|c|}{ current } & \multirow[t]{2}{*}{ Final } \\
\hline & & & & 1 & 2 & 3 & 4 & \\
\hline \multirow{2}{*}{$\begin{array}{l}\text { Quality of } \\
\text { life/ } \\
\text { activity } \\
\text { and } \\
\text { involment }\end{array}$} & SGRQ & $4 \ldots 7$ points $[13,14]$ & + & - & - & - & + & + \\
\hline & CRQ & $\begin{array}{l}0.5 \text { points, the average } \\
\text { score for the domain } \\
{[15]}\end{array}$ & + & - & - & - & + & + \\
\hline \multirow{7}{*}{$\begin{array}{l}\text { Course of } \\
\text { the } \\
\text { disease }\end{array}$} & $\mathrm{mMRC}$ & 2 points [16] & + & + & 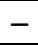 & + & + & + \\
\hline & CAT & $1.6 \ldots 3$ points $[13,17]$ & + & 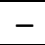 & 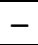 & - & + & + \\
\hline & $\mathrm{CCQ}$ & 0.4 points $[13,17]$ & + & - & - & - & + & + \\
\hline & BODE index & nd & + & 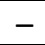 & 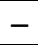 & 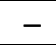 & 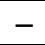 & + \\
\hline & $\begin{array}{l}\text { Period before } \\
\text { exacerbation after the PR }\end{array}$ & nd & - & - & - & - & - & + \\
\hline & $\begin{array}{l}\text { Number of exacerbations } \\
\text { per annum }\end{array}$ & $20-25 \%[18]$ & + & - & - & - & - & - \\
\hline & $\begin{array}{l}\text { Number of healthcare } \\
\text { visits to a doctor }\end{array}$ & nd & + & - & - & - & - & - \\
\hline \multirow{13}{*}{$\begin{array}{l}\text { Body } \\
\text { functions }\end{array}$} & Spirometry & $\begin{array}{l}100 \mathrm{ml} \text { for } \mathrm{FEV}_{1}[19] \\
100-140 \mathrm{ml}[20]\end{array}$ & + & $\begin{array}{c}++ \\
1\end{array}$ & - & $(+)$ & + & + \\
\hline & $\begin{array}{l}\text { repiratory rate } \\
\text { measurement }\end{array}$ & nd & + & + & & + & + & + \\
\hline & Oxymetry & nd & + & + & + & + & + & + \\
\hline & the Stange-Hench test & nd & + & + & + & + & + & + \\
\hline & Pulsometry & nd & + & + & + & + & + & + \\
\hline & Tonometry & nd & + & + & + & + & + & + \\
\hline & $6 \mathrm{MWT}$ & $54-80 \mathrm{~m}[21]$ & & & & & & \\
\hline & & $\begin{array}{l}26 \pm 2 \mathrm{~m}[22] \\
30 \mathrm{~m}[23]\end{array}$ & $+(?)$ & - & - & - & - & + \\
\hline & ISWT & $47.5 \mathrm{~m} \mathrm{[24]}$ & $+(?)$ & - & - & - & + & + \\
\hline & ESWT & $\begin{array}{l}45-85 \text { s [25] } \\
65 \text { s or } 95 \mathrm{~m}[26]\end{array}$ & $+(?)$ & - & - & - & + & + \\
\hline & 5STS test & $\begin{array}{l}\text { decrease of time from } \\
5 \text { to } 7 \mathrm{~s} \text { [27] }\end{array}$ & $+(?)$ & - & - & - & + & + \\
\hline & HADS & $\begin{array}{l}1.5[28] ; \\
\text { anxiety rating scale - } \\
1.7 \text { points, depression } \\
\text { rating scale }-1.5 \\
\text { points [29] }\end{array}$ & + & - & - & - & + & + \\
\hline & Chest volume & nd & + & - & - & - & + & + \\
\hline $\begin{array}{l}\text { Body } \\
\text { structure }\end{array}$ & Examination & nd & + & - & - & - & + & + \\
\hline $\begin{array}{l}\text { Educationa } \\
\text { I } \\
\text { competenc } \\
\text { e }\end{array}$ & $\begin{array}{l}\text { Bristol COPD Knowledge } \\
\text { Questionnaire }\end{array}$ & nd & + & - & - & - & - & + \\
\hline
\end{tabular}

Notes: $\mathrm{nd}-\mathrm{MCID}$ value is not defined;

1 - examination prior to a physical therapy session;

2 - examination in the course of a physical therapy session;

3 - examination after a physical therapy session;

4 - stage examination;

* - integral assessment of several groups of indicators;

$(+)$ - to use, if there are material and technical capabilities to conduct this study;

(?) - apply in the absence of contraindications, considering the course of the disease 
One of the first steps to substantiate the monitoring system of pulmonary rehabilitation was to determine the list of indicators and indices, which may be the inclusion criteria for patients to participate in the PR program, and thus serve as markers of effectiveness in the current control for the preliminary and final assessment.

The list of indicators and indices suitable for use in the monitoring system has been selected based on the analysis of clinical guidelines for PR and management of patients with COPD, randomized clinical trials included into the leading Cochrane Database of systematic reviews and devoted to rehabilitation and PT of patients with COPD [10].

In view of the recommendations of the clinical guidelines of the Global Initiative for Chronic Obstructive Lung Disease (GOLD, 2019) [30], the availability of research methods and the time and logistical support necessary for them, the frequency of their use in randomized clinical trials, 5 groups of indicators have been identified. Also, based on the results of this analysis, we have mainly selected indices for the monitoring of preliminary and final stages, and they have been divided into the main and additional (alternative ones), depending on how often they have been used as a research method.

The selection of indicators and indices for ongoing monitoring should be carried out taking into consideration the following principles: sensitivity (allows you to track the slightest changes in the patient's condition), simplicity (is difficult neither for the patient nor for the physical therapist), information value (provide the necessary data for the correction of rehabilitation intervention), and lack of training effect. Such frameworks provide SGRQ, CRQ, HADS, mMRC, CAT, CCQ, ISWT, ESWT, chest excursion, muscle strength measurements, respiratory rate, heart rate, blood pressure, $\mathrm{SpO} 2$, spirometry, and Stange and Genchi tests. Because of the pathogenetic changes in COPD and the selection of PT for their correction, we consider it to be appropriate to use such examination methods that take account of everything from the above. In particular, considering the decrease in the respiratory excursion and the increased residual lung volume, it is advisable to use anthropometric measurements of the chest excursion and separately evaluate the respiratory and expiratory excursions.

Since the Ministry of Health of Ukraine has not defined guidelines, established standards and criteria through which the effectiveness of the rehabilitation of patients with COPD can be assessed, a possible solution to this problem is to use the minimum clinically important difference criteria. This very assessment of changes in data modification takes into account the MCID in order to help to identify the clinically important benefits of one intervention compared to another [31]. However, this approach has also had some drawbacks, while the MCID may be different for the same parameter depending on the particularities of the methodology and calculation method; also, this value is not determined for each of the chosen indicators. So, the MCID value for the SGRQ questionnaire constitutes 4 points $[14,21]$. Alma $\mathrm{H}$. et al. believe that this indicator for patients with moderate and very complex COPD in PR makes up 7 points [13]. Similar differences have been found for the CAT questionnaire - the MCID value comes to 1.6 points [17] or 3 points [13]. The average MCID for evaluations of each of the four CRQ domains constitutes 0.5 points $[15,21]$; for the HADS scale that assesses the level of anxiety and depression -1.5 points (about $20 \%$ of the difference compared with the previous survey); for the CCQ questionnaire -0.4 points [13, 17]. The MCID for the distance traveled indicator (6MWD) with the 6MWT is 54-80 m [21]; however, when working with patients with a severe course of COPD, it makes up $26 \pm 2 \mathrm{~m} \mathrm{[22].} \mathrm{At} \mathrm{the}$ same time, the deterioration of test results compared to baseline examinations in patients with COPD over $30 \mathrm{~m}$ has been associated with an increased risk of death. Cazzola M. et al. [21] determined for FEV1 the recommended range of 100-140 ml, however, according to the data provided by Redelmeier D. A. et al. [20] and Donohue J. F. [19] a difference of $4 \%$ (100-112 ml) compared with the first examination can be considered clinically important. Difficulties exist in the interpretation of the MCID for the frequency of exacerbations, and the range of 20$15 \%$ can be treated as approximate one, as it has been calculated by comparing with the results of the SGRQ questionnaire [18]. The value of the MCID is uncertain or insufficiently verified for the mMRC scale [15], and limb muscle strength [17].

The idea of selecting research methods for evaluating each of the categories of the ICF has been popular [32, 33] among the researchers and leaders of applying the ICF in practice. Nowadays, there are few studies devoted to the selection of valid methods for assessing some ICF categories.

\section{Conclusion}

1. The process of pulmonary rehabilitation of people with COPD is an activity aimed at achieving the goal, and therefore requires an assessment and monitoring of its effectiveness in accordance with the expected results. The control system has been substantiated and is aimed at increasing the effectiveness of the physical therapist's performance in the course of pulmonary rehabilitation of people 
with COPD, which is implemented in three stages (preliminary, current, and final).

2. The control system within the competence of a physical therapy specialist provides for a rehabilitation examination (preliminary control), monitoring (current/ongoing control) and final assessment of specific indicators, allows you to track all changes in the patient's health condition and functioning, regulate interventions and their intensity, evaluate both a separate physical session therapy, and the effectiveness of the entire program. In view of the scientific and methodological data and the structure of the ICF, five groups of the main indicators that are used by the control subjects have been identified: quality of life/activity and involvement, course of the disease, body functions and body structure, educational competence.

3 . The selection of indices has been made for the selected groups of indicators, the features of their application at various stages have been determined, the values of the minimum clinically important difference for the selected indicators have been presented. The necessary volume of conducting research methods and determining indicators depends on the logistical support of the PT and PR processes in a particular institution, the monitoring stage, and compliance of patient's views with physical therapy specialist's vision.
4. Effectiveness of the PT and PR is one of the criteria of the control system, which is assessed on the basis of the dynamics and direction of changes in the studied indicators and their compliance with the expected result. Usually, the value of the minimum clinically important difference is taken into account in order to see not only the importance and direction of changes in the studied parameters but also to take into account whether these changes are clinically important.

Prospects for further research lie in the study - the MCID values for certain indicators with using basic and additional research methods.

The search for appropriate indices and indicators that can assess the presence of functional impairment in a specific category of ICF and qualify the level of these disorders and limitations, allows integrating the ICF into the rehabilitation process, providing control not only over the implementation of the PR programs and physical therapy, but also evaluating the performance of the rehabilitation care system for persons with COPD, in general.

\section{Conflict of interest}

Authors declare that there is no conflict of interest.

\section{References}

1. Tymruk-Skoropad K. Vykorystannia metodiv doslidzhennia $\mathrm{V}$ procesi legenevoi reabilitacii ta fizychnoi terapii osib z khronichnym obstruktyvnym zakhvoriuvanniam legen' (ogliad klinichnikh nastanov) [Use of research methods in the process of pulmonary rehabilitation and physical therapy of persons with chronic obstructive pulmonary disease (review of clinical guidelines)]. Slobozhans'kij naukovo-sportivnij visnik. 2018;4(65):5-12. https://doi.org/10.15391/snsv.2018-4.001.

2. Tymruk-Skoropad KA. Metody doslidzhennia efektyvnosti fizychnoi terapii ta legenevoi reabilitacii osib z khronichnym obstruktyvnym zakhvoriuvanniam legen' (analiz sistematichnikh ogliadiv) [Methods of investigation of the effectiveness of physical therapy and pulmonary rehabilitation of persons with chronic obstructive pulmonary disease (analysis of systematic reviews)]. Zdorov'ia, sport, reabilitaciia. 2018;4(4):148-57.

https://doi.org/10.5281/zenodo.1468312.

3. Zeng Y, Jiang F, Chen Y, et al. Exercise assessments and trainings of pulmonary rehabilitation in COPD: A literature review. Int J COPD 2018; 13: 2013-2023. http://dx.doi.org/10.2147/COPD.S167098

4. Sivak O. Rozvytok systemi reabilitacii - odyn iz prioritetiv MOZ [Oksana Sivak: Development of the rehabilitation system is one of the priorities of the
Ministry of Health] [Internet]. [cited 2019 Oct 11]. Available from:

https://moz.gov.ua/article/news/oksana-sivakrozvitok-sistemi-reabilitacii---odin-iz-prioritetivmoz-.

5. Iak zminiuiet'sia systema reabilitacii v Ukraini [How does the rehabilitation system in Ukraine change] [Internet]. [cited 2019 Oct 11]. Available from: https://moz.gov.ua/article/news/jak-zminjuetsjasistema-reabilitacii-v-ukraini

6. Novi posady i mul'tydisciplinarna komanda: MOZ Ukrainy prodovzhuie vprovadzhuvaty pidkhid dokazovoi reabilitacii $[\mathrm{New}$ posts and multidisciplinary team: Ministry of Health of Ukraine continues to implement an evidence-based rehabilitation approach] [Internet]. [cited 2019 Oct 11]. Available from: https://moz.gov.ua/article/news/novi-posadi-imultidisciplinarna-komanda-moz-ukrainiprodovzhue-vprovadzhuvati-pidhid-dokazovoireabilitacii.

7. Uriad zatverdyv plan zakhodiv iz vprovadzhennia Mizhnarodnoi klasifikacii funkcionuvannia [The Government has approved a plan of action to implement the International Classification of Functioning] / Kabinet Ministriv Ukrainy [Internet]. [cited 2019 Oct 11]. Available from: https://www.kmu.gov.ua/ua/news/uryad-zatverdiv- 
plan-zahodiv-z-vprovadzhennya-mizhnarodnoyiklasifikaciyi-funkcionuvannya

8. MOZ zatverdyv pereklad Mizhnarodnoi klasifikacii funkcionuvannia [The Ministry of Health has approved the translation of the International Classification of Functioning] [Internet]. [cited 2019 Oct 11]. Available from: https://moz.gov.ua/article/news/moz-zatverdivpereklad-mizhnarodnoi-klasifikacii-funkcionuvannja.

9. Tymruk-Skoropad K, Stupnic'ka S, Pavlova Iu. Misce fizichnoi terapii $\mathrm{v}$ systemi legenevoi reabilitacii pry khronichnomu obstruktyvnomu zakhvoriuvanni legen' (analiz klinichnykh nastanov) [Place of physical therapy in the system of pulmonary rehabilitation in chronic obstructive pulmonary disease (analysis of clinical guidelines)]. Fizichne vikhovannia, sport $i$ kul'tura zdorov'ia $u$ suchasnomu suspil'stvi. 2018;2(42):126-34.

10. Zdorova shkola: aspekty monitoryngu [Healthy school: aspects of monitoring] / Shiian O, Pavlova Iu, Kudrik L, Sorokolit N, Mikitiuk O; Shiian O, editor. Lviv: Kol'orove nebo, 2013. - 122 p.

11. Pavlova Iu. Ozdorovcho-rekreacijni tekhnologii ta iakist' zhittia liudiny: monografiia [Wellness and recreational technologies and quality of life: a monograph] / Iu. Pavlova. - Lviv: LSUPC, 2016. - 356 p.

12. Tymruk-Skoropad KA. Pervynne ociniuvannia ta planuvannia fizychnoi terapii paciientiv iz khronichnym obstruktyvnym zakhvoriuvanniam legen' z vykorystanniam instrumentiv na osnovi Mizhnarodnoi klasifikacii funkcionuvannia [Primary assessment and planning of physical therapy for patients with chronic obstructive pulmonary disease using tools based on the International Classification of Functioning]. Fizichna aktivnist', zdorov'ia i sport. 2018;1(31):45-53.

13. Alma H, De Jong C, Jelusic D, et al. Health status instruments for patients with COPD in pulmonary rehabilitation: Defining a minimal clinically important difference. NPJ Prim Care Respir Med; 26. Epub ahead of print 2016. http://dx.doi.org/10.1038/npjpcrm.2016.41.

14. Jones PW. St. George's Respiratory Questionnaire: MCID. COPD 2005; 2: 75-9.

15. Jones PW, Beeh KM., Chapman KR., et al. Minimal clinically important differences in pharmacological trials. Am J Respir Crit Care Med 2014; 189: 250-255. http://dx.doi.org/10.1164/rccm.201310-1863PP.

16. Bestall J, Paul EA, Garrod R, et al. Usefulness of the Medical Research Council (MRC) dyspnoea scale as a measure of disability in patients with chronic obstructive pulmonary disease. Thorax 1999 ; 54: 581586. http://dx.doi.org/10.1136/thx.54.7.581.

17. Kon SSC, Dilaver D, Mittal M, et al. The clinical COPD questionnaire: Response to pulmonary rehabilitation and minimal clinically important difference. Thorax 2014; 69: 793-798. http://dx.doi.org/10.1136/thoraxjnl-2013-204119.

18. Calverley PMA. Minimal clinically important difference--exacerbations of COPD. COPD 2005; 2: 143-8.
19. Donohue JF. Minimal clinically important differences in COPD lung function. COPD 2005; 2: 111-24.

20. Redelmeier DA, Goldstein RS, Min ST, et al. Spirometry and dyspnea in patients with COPD: When small differences mean little. Chest 1996; 109: 1163 1168. http://dx.doi.org/10.1378/chest.109.5.1163.

21. Cazzola M, MacNee W, Martinez FJ, et al. Outcomes for COPD pharmacological trials: From lung function to biomarkers. Eur Respir J 2008; 31: 416-468. http://dx.doi.org/10.1183/09031936.00099306.

22. Puhan MA, Chandra D, Mosenifar Z, et al. The minimal important difference of exercise tests in severe COPD. Eur Respir J 2011; 37: 784-790. http://dx.doi.org/10.1183/09031936.00063810.

23. Crapo RO, Casaburi R, Coates AL, et al. ATS statement: Guidelines for the six-minute walk test. Am Thorac Soc 2002; 166: 111-117.

24. Singh SJ, Jones PW, Evans R, et al. Minimum clinically important improvement for the incremental shuttle walking test. Thorax 2008; 63: 775-777. http://dx.doi.org/10.1136/thx.2007.081208.

25. Pepin V, Laviolette L, Brouillard C, et al. Significance of changes in endurance shuttle walking performance. Thorax 2011; 66: 115-120. http://dx.doi.org/10.1136/thx.2010.146159.

26. Revill SM, Morgan MD, Singh SJ, et al. The endurance shuttle walk: a new field test for the assessment of endurance capacity in chronic obstructive pulmonary disease. Thorax 1999; 54: 213-22. http://dx.doi.org/10.1136/thx.54.3.213.

27. Benaim C, Blaser S, Léger B, et al. 'Minimal clinically important difference' estimates of 6 commonly-used performance tests in patients with chronic musculoskeletal pain completing a work-related multidisciplinary rehabilitation program. BMC Musculoskelet Disord 2019; 20: 16. http://dx.doi.org/10.1186/s12891-018-2382-2.

28. Puhan MA, Frey M, Büchi S, et al. The minimal important difference of the hospital anxiety and depression scale in patients with chronic obstructive pulmonary disease. Health Qual Life Outcomes 2008; 6: 46. http://dx.doi.org/10.1186/1477-7525-6-46.

29. Smid DE, Franssen FM, Houben-Wilke S, et al. Responsiveness and MCID Estimates for CAT, CCQ, and HADS in Patients With COPD Undergoing Pulmonary Rehabilitation: A Prospective Analysis. $J$ Am Med Dir Assoc 2017; 18: 53-58. http://dx.doi.org/10.1016/j.jamda.2016.08.002.

30. Global Initiative for Chronic Obstructive Lung Disease Global Initiative for Chronic Obstructive Lung Disease: Pocket guide to COPD diagnosis, management, and prevention A Guide for Health Care Professionals, www.goldcopd.org (2019, accessed 28 May 2019).

31. Jones PW. Interpreting thresholds for a clinically significant change in health status in asthma and COPD. Eur Respir J 2002; 19: 398-404. http://dx.doi.org/10.1183/09031936.02.00063702.

32. Mel'nikova EV, Bujlova TV, Bodrova RA, Shmonin AA, Mal'ceva MN, Ivanova GE. Ispol'zovanie mezhdunarodnoj klassifikacii funkcionirovaniia 
(MKF) v ambulatornoj i stacionarnoj medicinskoj reabilitacii: instrukciia dlia specialistov [Use of the International Classification of Functioning (ICF) in outpatient and inpatient medical rehabilitation: instruction for specialists]. Vestnik Vosstanovitel'noj mediciny. 2017;6(82):1219-28.
33. Bui K-L, Nyberg A, Maltais F, et al. Functional Tests in Chronic Obstructive Pulmonary Disease, Part 1: Clinical Relevance and Links to the International Classification of Functioning, Disability, and Health. Ann Am Thorac Soc 2017; 14: 778-784. http://dx.doi.org/10.1513/AnnalsATS.201609-733AS.

\section{Information about author}

\section{Tymruk-Skoropad K.A.}

http://orcid.org/0000-0001-8152-0435

tymruk.k@gmail.com

Lviv State University of Physical Culture named after Ivan Boberskyj,

Kostyushka str., 11, Lviv, Ukraine, 79007

\section{Pavlova Iu.O.}

orcid.org/0000-0002-8111-4469

pavlova.j.o@gmail.com

Lviv State University of Physical Culture

Kostyushka Str., 11, Lviv, Ukraine, 79007

\section{Mazepa M.A.}

http://orcid.org/0000-0002-2199-4791

mrmazepa@ukr.net

Lviv State University of Physical Culture,

Kostyushka Str., 11, Lviv, Ukraine, 79007

\section{Інформація про авторів}

\section{Тимрук-Скоропад К.А.}

http://orcid.org/0000-0001-8152-0435

tymruk.k@gmail.com

Львівського державного університету фізичної культури імені Івана Боберського

Костюшка, 11, Львів, Украина, 79007

\section{Павлова Ю.О.}

orcid.org/0000-0002-8111-4469

pavlova.j.o@gmail.com

Львівський державний університет фізичної культури імені Івана Боберського

Костюшка, 11, Львів, Украина, 79007

\section{Мазепа М.A.}

Львівський державний університет фізичної культури імені Івана Боберського

Костюшка, 11, Львів, Украина, 79007 